\title{
The Expropriation of YPF from Repsol in the Argentine Press: Analyzing Framing in Opinion Pieces through Rhetorical Criticism
}

\section{La expropiación de YPF a Repsol en la prensa argentina: análisis del framing en las piezas de opinión mediante la crítica retórica}

María Luisa Azpíroz Manero. Center for International Relations Studies (CEFIR). University of de Liege, Belgium¹

Recibido: 27-II-2015 - Aceptado: 29-IX-2015

Abstract:

This article examines how opinion articles in the Argentine press framed the government's expropriation of Yacimientos Petrolíferos Fiscales (YPF) from Repsol in 2012. By understanding frames as narratives composed by the interrelation of the functions of frame, and adopting Kuyper's proposal to analyze framing from the perspective of rhetorical criticism, this study focuses on two newspapers with opposing editorial lines (La Nación and Página 12) and identifies two different narratives shaping the reporting of this story. The results also reveal two different views of the role of the market and the state in the economy and in the management of energy resources.

Keywords:

Framing; rhetorical criticism; Argentine press; opinion genre; expropriation of YPF.

Resumen:

Este artículo examina cómo los artículos de opinión de la prensa argentina enmarcaron la expropiación gubernamental de Yacimientos Petrolíferos Fiscales (YPF) a Repsol en 2012. Entendiendo los frames como narrativas compuestas por la interrelación de funciones de frame, y adoptando la propuesta de Kuypers de analizar el framing desde la crítica retórica, esta investigación se centra en dos periódicos con líneas editoriales contrapuestas (La Nación y Página 12) e identifica dos narrativas diferentes. Los resultados también revelan dos visiones diferentes sobre el papel del mercado y el Estado en la economía y la gestión de los recursos energéticos.

Palabras clave:

Framing; crítica retórica; prensa argentina, género de opinión, expropiación de YPF.

Postdoctoral fellowship financed by a BelPD-COFUND Fellowship (University of Liege \& Marie Curie Actions of the European Commission). 


\section{Introduction: The Expropriation of YPF from Repsol}

The expropriation of Yacimientos Petrolíferos Fiscales (YPF) from Repsol generated a serious diplomatic crisis between Argentina and Spain, at a critical moment of the European economic crisis. Numerous studies have analyzed the history of YPF, its privatization and later expropriation, from an economic and political perspective (see, for example, Costamagna, R. et al., 2015; Melgarejo Moreno, J., López Ortiz, M. I. \& Montaño Sanz, B., 2013; Barrera, M., Sabbatella, I. \& Serrani, E., 2012; Fernández, P., 2012; Large, J., 2012).

From the perspective of communication and media studies, it is interesting to analyze the coverage given to this case by the Argentine newspapers, given the intense attention that it received and the polarization of the media in this country. Koziner and Zunino (2013) applied content analysis and agenda-setting to determine the frequency, hierarchy and tone given to the expropriation of YPF on the covers and news articles of Argentine newspapers. However, a complete analysis of the coverage that the media give to a specific issue requires analysis of both information and opinion, and the combination of quantitative and qualitative methods. The aim of this article is to qualitatively analyze the discourse of the Argentine press as reflected in opinion pieces: framing is more evident in the genre of opinion and more subtle in the informative genre, given the pretension of objectivity in informative media. This article refines and shows the usefulness of a method based on framing and rhetorical criticism, which has already been applied to other case studies (see Azpíroz, $2014,2013,2012,2011$ ). As a necessary step for the application of the methodology proposed, a historical-political context concerning YPF and the expropriation is first provided.

The Argentine company YPF, founded in 1922, was privatized in 1993 by the government of Carlos Menem. This government established a strict monetary and fiscal discipline, liberalizing trade, deregulating finance, eliminating controls on foreign capital and privatizing state-owned enterprises (Rodrik, 2011). The aim of privatization was to reduce and refinance public debt, as well as to introduce technology into the industrial sectors (Costamagna et al., 2015). These measures corresponded to the proposals of the so-called “Washington Consensus" (Martínez \& Soto, 2012), and were supported by international financial organizations such as the World Bank and the Inter-American Development Bank (Melgarejo \& López, 2013). The privatization of YPF allowed it to issue debt in international financial markets with a better credit rating than that of Argentina, and at a lower cost. By 1999 Repsol, a multinational company domiciled in Spain, had bought 97.81\% ofYPF’s shares (Fernández, 2012).

In December 2001, in a context of economic recession, the Argentine economy collapsed and foreign capital took flight. The state, facing a serious economic, political and social crisis, restored capital controls, froze bank accounts, declared the default of external debt and devalued the currency (Large, 2012).

In 2003, the Kirchnerist government started a process designed to give a managerial role in the economy back to the state. This process included the formulation of monetary policies, the renegotiation of external debt, nationalization of private 
assets and industries such as those of Agua y Saneamientos Argentinos-AySA (2006), Administradoras de Fondos de Jubilaciones y Pensiones-AFJP (2008) and Aerolíneas Argentinas (2009), and a reform of the Central Bank charter (2012). More regulation in the hydrocarbon sector was also enacted, applying new taxes and creating the state-owned company Energía Argentina S.A. (Enarsa) in 2004, whose function would consist of importing gas and fuels that would cover the deficits in energy supply generated by the private sector (Koziner \& Zunino, 2013).

In 2008, with the aim of “Argentinizing” YPF, the business conglomerate Petersen Group, owned by the Argentine Eskenazi family, bought 15\% of YPF's shares from Repsol. By 2011 the group had bought more shares, now owning a total of $25.46 \%$ (Fernández, 2012). These purchases would be paid for using loans from a pool of banks and by a loan originating from the dividends of Repsol itself.

In May 2011, Repsol reported the existence of a field of unconventional resources in Vaca Muerta, in the Argentine province of Neuquén to the west of the country. It would be the third biggest deposit of this type globally, after those of the United States and China (Melgarejo, López \& Montaño, 2013). In December 2011, the Argentine "Pink House" began sending documents to Repsol's headquarters warning that it was not investing enough to increase output (Costamagna et al., 2015). Rumors about a likely expropriation of YPF began in January 2012. In a context of public diffusion of the Argentine energy deficit, the government and the oil provinces started pressuring YPF about its failure to fulfill contracts for exploration and sufficient production of hydrocarbons (Koziner \& Zunino, 2013). Several Argentine provinces canceled oil concessions to YPF, and by April the price of its shares had fallen by $41 \%$ (Fernández, 2012).

On April 16 2012, the Argentine government ordered an intervention into YPF, and sent to Parliament a draft bill to expropriate $51 \%$ of the company from Repsol, taking most of the $57.4 \%$ of YPF's shares that Repsol owned (Fernández, 2012). Of the shares expropriated, 51\% would be for the Argentine government and 49\% for the ten Argentine oil provinces (Costamagna et al., 2015). The remaining $49 \%$ of the shareholding structure of the company would remain in the hands of foreign investors with the aim of attracting additional investment capital to assist in alleviating the energy deficit (Koziner \& Zunino, 2013).

On April 25, the Argentine Senate approved the bill declaring self-sufficiency in hydrocarbon activity to be of national public interest, and the Argentine Congress approved it on May 3. After the nationalization, the Petersen Group was unable to service its debt, so the pool of banks and Repsol retained these shares (Melgarejo, López \& Montaño, 2013). Repsol, Spain and the European Union (EU) considered the expropriation "discriminatory" and alluded that it would be an infringement of the 1991 "Agreement for the reciprocal promotion and protection of investments between the Kingdom of Spain and the Argentine Republic" (United Nations Treaty Series, 1991).

The Spanish government perceived the expropriation of YPF as an act of hostility and as an affront to Spanish interests during a period of deep economic crisis (Costamagna et al., 2015). The expropriation was described as an "arbitrary" and "harmful" 
measure that represented a deterioration of friendly relations between the countries. References were also made to how Spain had previously helped Argentina in moments of difficulty. The first Spanish reprisal was to announce a reduction in the purchase of biodiesel from Argentina, prioritizing the purchase of European biodiesel (Melgarejo, López \& Montaño, 2013).

The EU demonstrated its support for Spain, warning of the negative effects that measures of this type have for European companies. The first measure adopted by the EU was to cancel the meeting of the EU-Argentina Joint Committee, which was scheduled for April 19 and 20. According to the European Commission, the expropriation could be illegal and was negative and harmful for investments and for the business environment in Argentina. However, although the Commission reiterated that the Lisbon Treaty makes foreign investment an "exclusive competence" of the EU, it also recognized the lack of legal mechanisms of pressure to make Argentina fulfill its commitments with regard to European investments in its territory (Costamagna et al., 2015). The European Parliament considered a partial suspension of unilateral customs preferences for Argentina (Melgarejo, López \& Montaño, 2013).

Once the expropriation was executed, the center of the debate was the compensation that Argentina should give to Repsol. The Argentine expropriation law says that Argentine tax courts are in charge of establishing the price of shares. In addition, the Calvo Doctrine applies in Argentina. This doctrine states that the parts residing abroad are subject to the jurisdiction of local courts, and not to diplomatic or military pressure from their countries of origin. Moreover, according to the Argentine government, the environmental damage caused by Repsol should be deducted from the payment. The president of Repsol, Antonio Brufau, determined that the compensation should be at least US $\$ 10.5$ billion. Faced with the refusal of the Argentine government to negotiate the value of the company, Brufau stated that Repsol would sue Argentina before the International Center for Settlement of Investment Disputes (ICSID), the arbitration institution of the World Bank for international investment cases.

The crisis of Repsol-YPF can be considered as finished in February 2014 with the signing of an agreement between Repsol and the Argentine government, in which the latter committed to pay US $\$ 5$ billion in compensation for the expropriation of Repsol's shares in YPF ( $E l$ País, 2014). In May 2014, Argentina paid to Repsol bonds worth US\$5.3 billion (El Economista/EFE, 2014).

\section{Methodology: Framing Analysis from a Rhetorical Criticism Perspective}

In the field of communication, framing is the process by which different actors use language to define and construct interpretations of issues and to connect them with a broader context (Kinder \& Nelson, 2005). In political communication, framing is the process by which political actors (politicians, the media, social movements, etc.) select and establish priorities when interpreting and explaining reality (Entman, 2008), appealing to symbols and ideas shared by members of the same society (Sádaba, 2008).

$36 \mid n^{\circ} 21$, pp. 33-53 | doxa.comunicación 
Framing theory can be applied to discourse analysis by employing different methodologies (quantitative, qualitative or mixed); methodological approaches (the quantitative linguistic, computer assisted and deductive, the qualitative hermeneutic, and the mixed manual holistic); and identifying different variables (such as framing mechanisms or reasoning mechanisms/functions of frame) (Azpíroz, 2014).

This study applies a qualitative methodology with a hermeneutic approach. This approach consists of the interpretative identification and account of frames based on small samples that reflect the discourse on a particular issue or event (Matthes \& Kohring, 2008). The analysis focuses on identifying the four functions of frame noted by Robert M. Entman (2008): problem definition, causal analysis, remedy and evaluation. The function "consequences" has also been added ${ }^{2}$. According to Entman (2008), the interrelation of the functions of frame composes the frames: narratives with which to promote a particular interpretation. Following Jim A. Kuypers' proposal (2009) to analyze framing from rhetorical criticism, employing a qualitative methodology, the identification and description of the functions of frame is done through a detailed textual analysis and is backed by textual evidence, referring to pieces whose content supports any statements made. This way, there is transparency in explaining how frames were extracted. Also according to Kuypers, the case study is approached with an open mind and by mastering its historical and political context.

As previously stated, in a newspaper as a whole, framing is more evident in the genre of opinion and more subtle in the informative genre, given its pretension of objectivity. Therefore, a sample including opinion pieces (editorials, columns, articles and interviews) that deal substantially with the expropriation of YPF from Repsol is considered as specially representative to analyze the frame of the media discourse. The sample of analysis includes the opinion pieces from $L a$ Nación and Página 12 during a ten-day period (17 to 26 April 2012), starting the day after the expropriation was announced by the Argentine government. First, the newspapers' editorial line is presented. Second, there is a framing analysis from the perspective of rhetorical criticism. Statements are supported by reference to a list of numbered pieces located in the appendix.

\section{Results: The Argentine Press Discourse}

\subsection{La Nación and Página 12: Opposed Editorial Lines}

La Nación is an Argentine newspaper founded in 1870 by the ex-president Bartolomé Mirtre. Its editorial line is politically center-right, and it has been traditionally linked with the interests of the Argentine landowning sector. Nevertheless, its

2 In this way, Entman's contribution is complementary with that of Gamson and Modigliani, who mention "causal analysis", "consequences and effects" and "appealing to principles" as reasoning mechanisms (they coincide with Entman in that "causal analysis", and "appealing to principles" would correspond with the "evaluation” function of frame) (Gamson \& Modigliani, 1989). 
opinion pieces include diverse signatures. Its motto is "La Nación will be a tribune of doctrine". It is the second highest selling newspaper in Argentina (after Clarin), with an average, in 2012, of 167,429 copies sold daily from Monday to Saturday, and 356,014 on Sundays (Koziner \& Zunino, 2013).

The Argentine newspaper Página 12, founded in 1987 by Jorge Lanata, was born as an "emblem of the new democratic time, a staunch defender of human rights" (Koziner \& Zunino, 2013). Its editorial line is center-left. It is characterized by its informal tone, its interpretative character, the depth of its informative reporting and by its practice of investigative journalism. It doesn't carry editorials but is styled with very original front pages rather different from those of traditional newspapers, with big photomontages that emphasize its point of view, and with more opinion pieces signed by journalists and collaborators (Hortiguera, 2007). Its average daily circulation in 2012 was around 16,000 copies ( Clarín, 2012).

\subsection{La Nación and the "Confiscation" of YPF}

\subsubsection{Problem Definition}

According to the frame of La Nación, the main problem was the incorrect and failed Kirchnerist energy policy $(1,3,7,8$, $13,15,24,41,45,46,50,51,52,54)$ which led to falls in production and reserves and to the end of energy self-sufficiency (which is a problem for the balance of payments), and which culminated in the "confiscation" (1, 3, 5, 21, 22, 30, 32, 34, 36, 37) of Repsol's shares in YPF.

\subsubsection{Causal Analysis}

Regarding the causes of the perceived errant energy policy, three arguments are emphasized. Firstly, the price regulation of energy products and consumption subsidies: in order to win votes (52), the Kirchnerist government fixed maximum prices $(8,46,48,53)$ for energy products, below the market level and without any relation to production and distribution costs or the cost of imports $(1,8,46)$. These prices were possible because the export of crude oil was subject to the payment of a mobile right (1), and the policy was enacted within a context of economic growth and recovery (that would have taken place anyway thanks to global commodity price increases) $(3,28,29,51)$. The consequence was an increased demand and a decreased offer of oil $(45,48,51,53)$; investment in exploration was discouraged as capital diverted towards countries that recognized prices which were closer to those of the international market (1). The supply-demand difference was compensated by international imports $(8,48,50,51)$, the purchase of which increased the fiscal deficit caused by the subsidies that kept consumption prices low $(8,48)$.

The second perceived cause is the Kirchnerists' "friends capitalism”, which in 2007 pressured Repsol by threatening to take concession areas from Repsol, which devalued the company (53) so that the Petersen Group, owned by the Argentine 
family Eskenazi, could acquire 25\% of YPF's shares $(2,3,8,9,13,24,32,50,53)$. The group didn't have the financial capacity to undertake this operation (53) and the government enabled it by authorizing the investment to be paid from future earnings of the company, funds which were deducted from the investment plans required to maintain a high level of output and reserves $(1,3,24,32,53)$. Repsol and the Eskenazis agreed to withdraw $90 \%$ of the profits for ten years, while the norm for the sector was $30 \%$ (40). In this way, with a massive distribution of dividends, productive resources were diverted to pay the debt $(1,3,8,16)$ : there was an extraordinary retirement of utilities, $255 \%$ in 2008 and $140 \%$ in $2009(51,52)$.

Lastly, there was a lack of reaction and responsibility from the civil servants of the Argentine Secretariat of Energy, who year after year approved the financial accounts of Repsol-YPF (which reflected the emptying of YPF and the distribution of dividends) and the company's exploration plans $(51,52,53)$.

\subsubsection{Remedy}

For La Nación the specific problem was the "confiscation" of Repsol's shares in YPF, and the root cause was the erroneous Kirchnerist energy policy. Regarding the "confiscation", it is stated that the Government should have followed the expected legal mechanisms for expropriations, making an agreed purchase or a hostile takeover of $100 \%$ of the shares (22). Regarding the energy policy, the importance of attracting and maintaining international investment $(2,3,5,7,8,11,15,16,22,24,28$, $37,46,48,49,52,53$ ), which is "the engine of the economy" (7) and turns natural resources into richness (48), is emphasized. The necessary requirements to attract investment are respect for private property, monetary and fiscal discipline, clear game rules and giving profitable prices to investors $(48,53)$. The State and its institutions must favor these conditions (48). A policy that favors the market is mentioned as the most practical and specific way to promote development (53).

\subsubsection{Consequences}

In La Nación, a range of consequences of the "confiscation" of YPF are mentioned. Such measures go against legal certainty $(1,2,7,11)$, and strangle the private sector and discourage investment $(2,3,5,22,31,37)$. Argentina's country risk soared, so achieving foreign capital to finance projects and investments, like those necessary to turn the unconventional gas reserves of Vaca Muerta into reserves (7, 8, 46), will cost more (3, 6, 11, 16, 22, 24, 45, 49). Overall, the lack of investment will make Argentina more dependent on commodities, will accelerate its de-industrialization and will increase its poverty (28). The integration of Argentina into the international economy will be damaged (50).

In terms of international relations, a bilateral crisis $(1,29,46,49)$ with Spain is created, which has as "hostages" its huge investments in Argentina (21). Relations with an EU showing solidarity (7, 16, 46, 49) with Spain, and which may demand international sanctions against Argentina, are damaged (29). And the possibility, "scarce in advance", of a future EUMercosur free trade agreement is reduced $(13,29)$. There is also potential harm to relations with the United States, which 
"loathes the single image of a state expropriating private property" $(7,16,22)$. Furthermore, diplomatic efforts to obtain international support for the Argentine claim on the Malvines Islands get complicated $(3,13)$.

There are also mentions of the damage that the "confiscation" of YPF does to Argentina's image $(3,37)$ and progress, in comparison with its neighbors $(2,7,16,21,29,46)$, and which may sow investors' distrust in Latin America generally (49). In this respect, on the one hand there are descriptions of Latin American countries (including the "most successful ones", Brazil and Mexico), which are characterized by their formidable "capture of investments", by their integration into the world economy and by their consolidation of stable democracies $(13,15,22,34,46)$. On the other hand there is the "catastrophic paradigm" of "radical populism" and its economic decline, exemplified by the "Bolivarian" bloc of Venezuela, Ecuador, Bolivia and Nicaragua (and to which the Argentine government could well have consigned Argentina) $(3,19,29$, $45,49)$.

\subsubsection{Evaluation}

The evaluative components make reference to two main questions: firstly, to the specific measure of "confiscation", including its legal and formal aspects and, secondly, to Kirchnerism, both regarding the YPF "confiscation" and in general.

Regarding the YPF "confiscation" (1, 3, 5, 21, 22, 30, 32, 34, 36, 37) from Repsol, there is criticism of the procedure followed (hence the denomination "confiscation"), even more than criticism of the fact of expropriation itself. However, there are only a few minority voices (mainly external to the newspaper and of center-left political views) which positively value the expropriation in itself, alluding to the "strategic importance", the "symbolic value" and the relevance of YPF for national "sovereignty" $(39,47)$, as well as to the "historic value" (20) of the decision and to the logic of having a public company in the oil sector (55).

Criticism of the procedure of YPF "confiscation" is due to both legal and formal reasons. In legal terms, the expropriation procedure contradicts the Argentine Constitution, laws and international treaties signed (5, 10, 21, 22). It is a "confiscation in violation of the Constitution" (3). The measure is described as "useless audacity" (13), "interventionist” (2, 10, 30), a "crime" (22, 24), "illegal" (3), with "legal flaws" (30), and contrary to the right of ownership (3), since the public sector advanced over the private sector "outside the law" (8). With the expropriation, legal procedures and international commitments assumed by Argentina are disregarded (24). The measure is also considered as "arbitrary" and "discriminatory", since it falls only on Repsol $(2,22,45)$. The "bad faith" of the Argentine government is highlighted, since Repsol was systematically attacked by the state in order to diminish the price of their assets. The governors of Argentine provinces were accomplices to this, cancelling concessions of areas awarded to YPF (2).

To support these considerations there are allusions, firstly, to Article 17 of the Argentine Constitution, which talks about an expropriation for reasons of public utility only when "authorized by law and previously compensated" (3, 10, 14, 16, 21, 
$22,30,37)$. The compensation must be equivalent to the economic value of the expropriated object (3). Secondly, to the Argentine expropriation law 21499, which establishes that when a property is expropriated "the state must make an offer of the price, and if the owner doesn't accept that compensation it must sponsor a suit. Only then, with the intervention of a judge, valuation of the property and deposit of that compensation, can the state take over the property or company" (10). A Decree of Necessity and Urgency is not enough to take over a private company, since a judicial decision is required $(14,22)$. Thirdly, there is allusion to the bilateral investment treaty signed with Spain (45). Finally, to the company's clause of corporate status, which establishes that in order to acquire more than $15 \%$ of its shares, a public offer for all of them must be made (30).

Regarding the symbolism of the action, it is criticized that the expropriation seemed to be a "declaration of war" by Kirchnerism against Spain (7), that it recalled "old images of a state coup" (12), with an "insulting and discriminatory" eviction of its owners (22). The Kirchnerist government avoided use of "any civilized system to agree differences" (12), and acted with "exasperation and punishment for all" (3).

Kirchnerism as a governing philosophy is attacked and the "confiscation" is seen as a tactic of distraction or compensation, in the short term $(21,27,41,49)$, for its wrong policies and for the decline of its popularity: "that oil, ours or from others, takes care of the expenses of populism" $(7,13)$; "distracting for a short period public opinion from the serious problems [...] (49)"; by such a "last ditch effort" (16), "it is ensured that followers [...] forgive authoritarianism, venality and disasters" (20). It is considered that the YPF "confiscation" represents a project of governmental power (32), that YPF is being put in the hands not of the state but of the government (44). The idea that Kirchnerism wants to use the oil company to strengthen the political "purse" is repeated $(1,3,15,27)$. There is also criticism of Kirchnerism's changing "teenager" behavior, since years before it had applauded the privatization of $\operatorname{YPF}(3,7,9,20,33,44,50)$. Finally, there are warnings about a misguided nationalism, which had already occurred in the cases of the Malvines and the default: measures applauded at the time but that later nobody admitted having supported $(28,37,54)$.

Regarding Kirchnerism in general, there are many allusions to the "populism" (7, 13, 29, 41, 44, 46, 48, 49, 50) that its measures denote (past and present). There is also talk of "jingoism" (27, 38, 49), "demagoguery" (34, 49, 50), "nationalist exaltation" (3), "dogmatism" (24) and a lack of self-criticism $(18,33)$. There is allusion to the contradiction of this type of government with what a republic and its separation of powers should represent $(3,21,38)$. Also the physiocracy of the government and politicians is criticized, describing the idea that social progress is determined by the possession of natural resources as a prejudice $(8,22)$. Peronism, on which Kirchnerism is based, is described as a "confused ideology" that when in power impoverishes the country with "demagogic policies" (49). The most critical stance mentions the anachronistic policies towards which Kirchnerism tends (economic nationalism, inward development, state control), and which only increase poverty (49). 
In contrast, and although they are in a minority, in La Nación there are also voices that defend the "sovereign state" and "energy sovereignty" against the vision of a peripheral and subordinate country $(39,55)$, as well as being supportive of the development fostered by the Kirchnerist economic model, which is not explained by any "tailwind" (39). In this line, there is a critique of the neoliberal vision of markets, of the deregulation and subordination to financial speculation that, as is characterized as happening in Europe, leads to unemployment and suicides (55).

\subsection{Página 12 and the "Recovery" of YPF}

\subsubsection{Problem Definition}

To Página 12 the problem was Repsol's low output and investment in Argentina (39), which led to a decline in reserves and to a rapid increase in imports of hydrocarbons $(36,39)$, widening the "external energy gap" (3). Thus, energy self-sufficiency was unachievable and problems were created, not only of consumption (39) but also macroeconomic (39). There was a deficit in the trade balance and a reduction to the surplus in the balance of payments $(34,36,39)$. Since Argentina was mostly excluded from obtaining loans from international financial markets, it was important to count on a favorable trade balance and to hold sufficient foreign exchange reserves in order to avoid a crisis in the balance of payments (39).

\subsubsection{Causal Analysis}

Página 12 identifies specific causes of Repsol's low output and investment, which in turn are explained by broader causes that have to do with the neoliberal model and with Argentine history (1).

As specific causes, the "predatory policy" of oil wells $(1,34)$ and the "pillaging" (32) conducted by Repsol, which earmarked production mainly for export in order to profit from rising oil prices (18) and to finance its global expansion (1, 23), are cited. There are denunciations of the abusive remittance of profits abroad $(18,20,21,25,30,34)$, more than US\$9 billion in 14 years (5), to the detriment of investment plans and reserves $(1,3,15,18,20,21,25,30,32,34)$. It is noted that the indebtedness of Repsol and the Eskenazi family (thanks to a misstep from the Kirchnerist government) contributed to the emptying and to the unreservedly predatory extraction of oil wells $(3,28 \mathrm{~b})$. Repsol's performance was contrary to its contractual rules $(25)$ and norms $(25,28)$, failing in its social ethical duty arising from the hospitality provided by Argentina and therefore contrary to Article 75 (on human development) of the Argentine Constitution (34), becoming an obstacle to the development and the interests of the Argentine nation $(20,21)$.

As neoliberal representatives, Repsol and the Spanish capitalists (only once is it stressed that Repsol is a multinational and not solely a Spanish company) (13) are accused of acting as "nouveaux riches" $(1,3)$ in bankruptcy $(10)$, with the neocolonialist arrogance and indifference $(3,6,10)$ of an "ex-colonial metropolis" (32) "in decline" (3), who see the profits from 
the second conquest of America collapsing (10), profits that they wanted to use as floats amid the wreck of the economic crisis (10). Their attitude is a demonstration of their weakness, caused by a suicidal policy of austerity and adjustment (1). The Spanish government is accused of appearing as the agent of a predatory company (32) and of planning to use Repsol's profits as "grandma's jewelry" to charge Argentines for the European crisis (23). A "Spanish right" elite is seen as producing a chauvinist discourse against Argentina, and is viewed as a common enemy, with the Argentine right-of-center elite (28). In contrast, the good relationship and mutual help that historically has taken place between the Argentine and the Spanish people is highlighted $(3,5,33)$.

The "historical" cause of the Repsol-YPF situation is the struggle, for more than 200 years, between two projects of nation (24): the project of the alliances among the oligarchies and the empire of turn, on the one hand, and the project of the entity nation-popular sectors, on the other (35): these projects would currently correspond to the neoliberal model and to the Kirchnerist model. This struggle prevented Argentina from reaching the levels of development needed to fully exercise its political sovereignty (35).

\subsubsection{Remedy}

According to Página 12, the case of Repsol-YPF proves that the output and management of energy cannot be left to the private sector $(23,39)$ or to neoliberal regulation $(23)$, which compromises the development of a country in favor of the profit-driven nature of large companies (33). Energy production and the appropriation of the income resulting from the exploitation of natural resources are of interest to the entire Argentine people, who are the ultimate owners of such (33). Kirchnerism had already adopted some measures: price regulation, the arrival of the Eskenazi family (who nevertheless ended up copying the behavior of the Spaniards) and taxes on exports (18). These measures were not enough; therefore, the solution needed to counter Repsol's conduct and to recover energy self-sufficiency had to confront the energy model of deregulation and privatization.

With the expropriation and the declaration of energy self-sufficiency of national public interest, the control and right to decide a national hydrocarbons policy is recovered $(1,5,23,26,33)$. This contributes, according to the Kirchnerist model, to an autonomous and inclusive model of development $(19,21,28,34)$. Some voices argue that such a recovery of selfsufficiency and sovereign control of resources should take place in Latin America as a whole (19, 39).

Other voices highlight that the notion of self-sufficiency must include not only the need for fuel, but also the need for a national productive system that replaces the numerous imports of by-products and also contributes to industrialization, to the trade balance and to a macroeconomic balance $(1,17,20,28 \mathrm{a})$. Regarding the link between foreign direct investment (FDI) and development, there is a call for investments to take place in the framework of a national development policy, as has happened in China, Korea and Japan $(29,34)$. The idea that domestic savings are the main source of economic development is noted (29). 


\subsubsection{Consequences}

In Página 12 there is the idea that the state management of YPF will improve its functioning and increase its output above that of private management, because the calculations of costs and benefits are not the same $(15,23)$. The benefits of state over private management have been already demonstrated, in their view, by the cases of the Post, Agua y Saneamientos Argentinos S.A. (AySA), Aerolíneas Argentinas and Administración Nacional de la Seguridad Social (ANSES) (16).

However, securing the positive "recovery" of YPF's focus relies, to a great extent, on repelling external pressures. Economically, it is considered that both the EU and Spain, at the height of a financial crisis, are not in a position to be too intimidating $(13,16,39)$. Thus the threat of reprisals from European and US companies, which would look to take advantage of any opportunities offered by the new situation of YPF, is minimal (8). Spain is considered to have much more to lose than to win in a confrontation with Argentina: Argentine imports from Spain twice as much as Spain exports to Argentina; Spain is the principal foreign investor in Argentina; large Spanish companies operate in Argentina and Spain itself would be the most affected by limitations on imports of Argentine biodiesel $(8,13)$. Besides, the possibility of trade retaliation is rejected because the World Trade Organization forbids trade discrimination (8). International financial organizations "are not concerned" to opine about a national sovereignty decision (25), and the rating agencies have no credibility after their mistakes in the mortgage crisis in the US (39).

At the international level, it is considered that Argentina has major regional support, and that in most of South America the role of the state and the government in the management of hydrocarbons is not questioned $(4,16)$. There is also talk of the "interested ambiguity" of the United States and the "cunning silence" of China (16). Regarding Repsol's possible appeal to the International Centre for Settlement of Investment Disputes (ICSID), the slowness of the process is stressed (13) and the benefits of being a member are questioned $(26,28 \mathrm{c}$ ) (Brazil, Bolivia, Ecuador and Venezuela are not members). Contesting bilateral investment treaties, which involve conditions that are seen as detrimental to the national interest, is also suggested (28c).

\subsubsection{Evaluation}

The evaluative component in the frame of Página 12 has several levels: one that values the specific measure of the expropriation of YPF in the context of Kirchnerism, another that concentrates on the legal aspects, and a broader one that focuses on the evaluation of two economic models, neoliberalism and Kirchnerism.

The measure of expropriating YPF is described as the "recovery" $(5,6,18,20,37)$ of YPF and as a recuperation of "energy sovereignty" (1, 3). Terms like "historical" $(3,6,28)$, "ambitious" (2) and a "symbolic" (2) measure are employed. It is a measure of "correction" (16), "repair" (1), "reversal" (39) and for "dismantling" (6) the neoliberal policies of the 1990s. It is a measure consistent with the establishment of a national policy of hydrocarbons since it permits the state to recover

44 | n 21, pp. 33-53 | doxa.comunicación 
control of the company and to acquire an intervention tool in the sector (23). It is an opportunity to show how the state can efficiently manage a "strategic enterprise" (33), the "main strategic asset of the country" (20). In this sense, the actual adoption of the measure is considered a sign of self-criticism by Kirchnerism, which in the 1990s supported the privatization of YPF $(6,7,13)$.

To Página 12 the expropriation is legal $(5,16,25,28 \mathrm{c}, 34)$ and all regulatory steps are being followed, because there is an executive power and a legislative power working (25). The expropriation is backed by the national constitution $(2,5,34)$ : Article 14 which approves the expropriation for cause of public utility (2, 34), and Article 75 on human development (34) are cited, and it is stressed that the bill as designed determines public interest, sets goals and includes compensation (2, 26). The Civil Code is also mentioned: Article 2512, which regulates temporary occupation (34). It is denied that there has been discrimination against Repsol, since its control of capital and its dominant position were taken into account, and other private companies in the sector don't have as poor a record regarding investments and activities (34). Only one voice (from the UCR party) criticizes that there was not an agreed sale (28b).

The opinion of Página 12 frequently contrasts two conceptions about the functioning of the economy, the role that the state must play in it and the energy model that must be adopted: the neoliberal and the Kirchnerist model (which the newspaper supports).

The neoliberal model that dominated the 1990s $(1,6,16,39)$ began to be introduced in Argentina during the cycle of economic opening up, deregulation and privatization of the mid-1970s $(38,40)$. It "degraded" the country's political practices and Peronism (28). According to the prescriptions of the Washington Consensus (24), in the economy, corporate gain (18), excessive profit eagerness (17), capitalist interests (15) and meeting financial criteria $(17,29)$ come first and above any collective right of a nation or its citizens (15). The curse of globalization occurs: peripheral states are linked to the world market in a subordinate way and have less value than multinationals, and only the interests of the center exist (20, 29). The "terrorists of finances" and multinationals refer to a "legal certainty" designed to enrich them, and which involves comfortable contracts that commit governments, while they can violate them without consequence or penalty $(9,31,32)$. The state is an obstacle to the interests of private capital $(9,32)$, and public policies for development should be dismantled (29). Many states don't omit servitude to private interests (32).

The neoliberal energy model is characterized by deregulation and privatization (1). Hydrocarbon resources are considered a commodity $(1,19)$, a merchandise (35) of free availability (1) and without strategic value (19). The private right to maximize profits prevails (1) and there is no commitment to investment, reserves or self-sufficiency $(1,33)$.

An example of the failure of the neoliberal model is seen in the 2008 economic crisis and the disasters (unemployment, suicides) that are perceived as ensuing in Europe $(31,33)$. The neoliberal remedy, percolated through international financial 
organizations (31), is to prescribe austerity and adjustment policies that are charged on the popular classes $(13,33,49)$ and which only deepen the crisis (31).

The Kirchnerist model, started in 2003, is described as anti-neoliberal $(24,38)$, national $(29,37)$, popular $(24,37)$, and democratic $(24,37)$. It is defined as a cultural transformation $(28,38)$ that implies a change in the conception of the role that the state must play in the development and management of the resources needed for this transformation (38), and which is characterized by public policies of transformation and by the recovery of national sovereignty (24). The model is coherent with the processes of liberation of Peronism (35) and with the "Calvo Doctrine", based on the principles of national sovereignty and territorial jurisdiction (8).

According to the Kirchnerist model, what should prevail in the economy is the national interest $(18,20,31)$, the social interest (25) and the public need (25), rather than multinational capital, with which a sovereign and intelligent relationship must be built (20). A pattern of accumulation of capital led by the state must be realized, with significant investment of that capital into the industrial and technological development of the nation $(22,29,33,35)$. Sovereignty and autonomy of decisions $(22,29)$ for the state serving that development must be achieved (29), and the state that must play a strategic planning role $(1,12,20)$ in the economy. It is a model of economic growth and autonomous development with inclusion and social justice (34).

The Kirchnerist energy model is characterized by a desire for self-sufficiency $(19,35)$ and sovereignty $(1,3,28 \mathrm{~b}, 33)$ that "transcends the economic issue and is installed as an essential political objective" (19). Hydrocarbon resources are considered strategic resources $(1,27,35,36)$, important because of their scarcity, their non-renewable nature and because they are essential for industrialization $(1,18,35)$. Therefore, the state must intervene in the management and control of the hydrocarbons market (1).

In general terms, Kirchnerism's sustainability and economic success is praised (2, 39). A success despite the fact that Argentina receives very little direct foreign investment, and that it is largely rejected by international markets: the most important groups to please according to the business press (39). In defense of the Kirchnerist energy model, it is argued that all oil producing countries continued to consider their hydrocarbon resources as strategic despite the neoliberal wave, and that leading producer countries still also manage their oil with state policies: the cases of Saudi Arabia, Norway and Brazil are cited $(1,25,39)$. The "recovery" of YPF would be in line with other advances in the recovery of lost sovereignty caused by neoliberalism, like the nationalization of the Post, Aerolíneas Argentinas, and the funds of the AFJP (2, 16, 29, 38). All these companies are seen as working better nationalized than privatized (16). 


\section{Conclusions}

1) The frames or narratives transmitted by La Nación and Página 12 about the expropriation of YPF from Repsol are completely opposed. La Nación conveys a negative frame ("confiscation" of YPF) and Página 12 a positive one ("recovery" of YPF). In fact, in the case of La Nación the expropriation is located in the function "problem definition", and in Página 12 in the function "remedy". Nevertheless, in both cases the function "consequences" is focused on the expropriation of YPF (in Página 12 they would be "consequences" of the "remedy" and not of the "problem").

2) For La Nación, the main element to blame for the end of energy self-sufficiency is the Kirchnerist energy policy, and for Página 12 it is Repsol's bad management. That is why the frame of La Nación doesn't consider the expropriation as a good remedy, pointing to international investment as being the key (although it criticizes the procedure of the expropriation, describing it as a "confiscation", more than the motive behind it). On the contrary, Página 12 frames the "recovery" of YPF as the solution to Repsol's bad management: a solution that is also coherent with the economic and energy model represented by Kirchnerism. The frames of La Nación and of Página 12 criticize and praise, respectively, the Kirchnerist economic and energy model, contrasting it with what Página 12 calls the neoliberal model.

3) It is worth noting that in La Nación the function "evaluation" does give a little space to voices in disagreement with the dominant frame, while in Página 12 only minimal criticism is found, chiefly expressed as forgiveness of Kirchnerism for previously having supported the privatization of YPF and the entry of the Eskenazi family. Therefore, opinion pieces in $L a$ Nación offer a little more pluralism.

4) The different way of framing the expropriation of YPF in both newspapers is coherent with the studies that state that, throughout Argentine history, there have been two views on energy public policy: one that understands hydrocarbons as non-renewable and strategic resources for economic development, and another that understands hydrocarbons as commodities (Barrera et al., 2012, cited in Koziner \& Zunino, 2013).

5) Koziner \& Zunino (2013) apply the theory of agenda-setting to analyze the coverage of the expropriation of YPF by the Argentine press. Their results show the frequency of coverage through time, the hierarchy of information and the positive or negative tone of information and opinion pieces. The comparison of their results with the results of this study shows that using framing analysis from a rhetorical perspective complements and deepens the results obtained by the application of other theories and methodologies of communication research. 


\section{Bibliographical References}

\section{Academic Sources}

Azpíroz, M. L. (2014): “Framing and Political Discourse Analysis: Bush's Trip to Europe in 2005”, Observatorio (OBS*), v. 8, n. 3, pp. 075-096.

- (2013): “ Framing as a Tool for Mediatic Diplomacy Analysis: Study of George W. Bush’s Political Discourse in the 'War on Terror”, Communication and Society, v. 26, n. 2, pp. 176-197.

- (2012): Diplomacia pública: El caso de la "guerra contra el terror". Barcelona: UOC.

- (2011): La diplomacia pública estadounidense de la "Guerra contra el Terror": análisis y evaluación de su influencia en la prensa española. Doctoral Thesis. http://dadun.unav.edu/handle/10171/37305 [Accessed: Apr. 13, 2015].

Barrera, M., Sabbatella, I. \& Serrani, E. (2012): Historia de una privatización: Cómo y por qué se perdió YPF. Buenos Aires: Capital Intelectual.

Costamagna, R. et al. (2015): “Repsol-YPF: An 'illegal' expropriation”, Journal of Business Research, v. 68, n. 2, pp. 255-262.

Entman, R.M. (2008): “Theorizing Mediated Public Diplomacy: The U.S. Case”, The International Journal of Press/Politics, v. 3, n. 2, pp. 87-102.

Fernández, P. (2012): Valoración de una expropiación: YPF y Repsol en Argentina. Documento de Investigación WP-1055. Madrid: IESE Business School.

Gamson, W. \& Modigliani, A. (1989): "Media discourse and Public Opinion on Nuclear Power: A Constructionist Approach”, American Journal of Sociology, v. 95, n. 1, pp. 01-37.

Hortiguera, H. (2007): “La mirada argentina: ¿Desvíos o desvaríos de la prensa gráfica? El caso Página/12”, Revista de crítica literaria y de cultura, n. 16, pp. 01-16.

Kinder, D.R. \& Nelson, T. E. (2005): “Democratic Debate and Real Opinions”, in Callaghan, K.J. y Schnell, F. (eds.): Framing American Politics. Pittsburgh: University of Pittsburgh Press, pp. 103-122.

Koziner, N. \& Zunino, E. (2013): “La cobertura mediática de la estatización de YPF en la prensa argentina: un análisis comparativo entre los principales diarios del país”, Global Media Journal México, v. 10, n. 19, pp. 01-25.

Kuypers, J. A. (2009): “Framing Analysis from a Rhetorical Perspective”, in D’Angelo, P. \& Kuypers, J. A. (eds.): Doing News Framing Analysis: Empirical and Theoretical Perspectives. New York: Routledge, pp. 286-311.

Large, J. (2012): “Nationalization, the big picture”, Revista de Negocios Internacionales, v. 5, n. 1, pp. 55-61.

Martínez Rangel, R. \& Soto Reyes Garmendia, E. (2012): “El Consenso de Washington: la instauración de las políticas neoliberales en América Latina”, Política y Cultura, n. 37, pp. 35-64. 
Matthes, J. \& Kohring, M. (2008): “The Content Analysis of Media Frames: Toward Improving Reliability and Validity”, Journal of Communication, v. 58, n. 2, pp. 258-279.

Melgarejo Moreno, J., López Ortiz, M.I. \& Montaño Sanz, B. (2013): “From Privatisation to Nationalization: Repsol-YPF, 1999-2012", Utilities Policy, v. 26, pp. 45-55.

Rodrik, D. (2011): The Globalization Paradox: Democracy and the Future of the World Economy. New York: W.W. Norton.

Sádaba, T. (2008): Framing, el encuadre de las noticias. El binomio terrorismo-medios. Buenos Aires: La Crujía.

\section{Official Sources}

United Nations-Treaty Series (1991): Agreement between the Argentine Republic and the Kingdom of Spain on the Reciprocal Promotion and Protection of Investments. (Translation) http://www.wipo.int/edocs/lexdocs/treaties/en/ar-es/ trt_ar_es.pdf [Accessed: Oct. 27, 2014].

\section{Media Sources}

Clarín, "Publicidad oficial: más plata a los diarios que menos venden”, Alejandro Alfie, 29/06/2012.

El Economista/EFE, “Repsol culmina la venta de bonos argentinos y de su participación en YPF”, 08/05/2014.

El País, "Repsol y el Gobierno de Argentina firman el acuerdo de YPF”, Francisco Peregil, 28/02/2014.

\section{Appendix}

A) Sample of La Nación's Discourse Analysis

Internal Opinion

(1) YPF: la confesión de un fracaso, Editorial, 17/04/2012

(2) YPF: arbitrariedad y mala fe, Editorial, 18/04/2012

(3) YPF, una confiscación, no una expropiación, Editorial, 21/04/2012

(4) La oposición frente a la confiscación, Editorial, 22/04/2012

(5) Desbaratamiento de derechos, Editorial, 23/04/2012

(6) Kicillof y la seguridad jurídica, Editorial, 26/04/2012

(7) La presidenta le dio un portazo al mundo, Joaquín Morales Sola, 17/04/2012

(8) Debajo de la gesta patriótica asoman varias falacias, Carlos Pagni, 1704/2012

(9) Una alusión errónea al gran privatizador: Néstor Kirchner, Francisco Olivera, 17/04/2012

(10) Apoderarse sin previo pago, Adrián Ventura, 17/04/2012 
(11) Cristina ya fracasó con su petrolera estatal, Jorge Oviedo, 17/04/2012

(12) Dinero y encuestas, las grandes razones, Joaquín Morales Sola, 18/04/2012

(13) Los cuatro dilemas que enredan a Kicillof, Carlos Pagni, 19/04/2012

(14) El alto costo de la expropiación, Adrián Ventura, 19/04/2012

(15) Trazar los límites al Gobierno, Natalio R. Botana, 19/04/2012

(16) ¿ Otro manotazo de ahogado?, Luis Majul, 19/04/2012

(17) Peleados con el mundo, Fernando Laborda, 20/04/2012

(18) La descomposición política del país, Eduardo Fidanza, 20/04/2012

(19) YPF, una resurrección con sabor a epopeya, Carlos M. Reymundo Roberts, 21/04/2012

(20) Carta urgente para una prima española, Jorge Fernández Díaz, 22/04/2012

(21) Cristina, ¿̇tan dominante como Hugo Chávez?, Mariano Grondona, 22/04/2012

(22) La peor crisis internacional desde el default, Joaquín Morales Sola, 22/04/2012

(23) Agazapados tras los despojos de Repsol, Francisco Olivera, 22/04/2012

(24) Tirarse a la pileta sin medir el agua, Néstor O. Scibona, 22/04/2012

(25) El viejo truco de la causa nacional, Pablo Mendelevich, 22/04/2012

(26) Los aliados invalorables de la Presidenta, Carlos Pagni, 23/04/2012

(27) La presidenta que podría ser, Marcus Aguinis, 24/04/2012

(28) La Argentina, ¿a contramano del mundo?, Andrés Oppenheimer, 24/04/2012

(29) Las garantías se convierten en una nostalgia, Joaquín Morales Sola, 25/04/2012

(30) Apoyos clave para el sueño de ir por más, Carlos Pagni, 26/04/2012

(31) Ella volvió a ganar y piensa en 2015, Luis Majul, 26/04/2012

(32) Efectivamente, van por todo, Fernando Laborda, lanacion.com, 17/04/2012

(33) Cristina comenzó a gobernar, Daniel Pliner, lanacion.com, 18/04/2012

(34) ¿̇Otra vez, Braden o Perón?, Mariano Grondona, lanacion.com, 19/04/2012

(35) La Policía Progre ya custodia YPF, Diego Sehinkman, lanacion.com, 19/04/2012

(36) Se viene cotillón cristinista, Martín Dinatale, lanacion.com, 23/04/2012

$50 \mid n^{\circ} 21$, pp. 33-53 | doxa.comunicación 
(37) El clima inversor, gravemente herido, Fernando Laborda, lanacion.com, 24/04/2012

(38) El patriotismo patotero, Sergio Sinay, lanacion.com, 25/04/2012

External Opinion

(39) El mejor ejemplo de la sintonía fina, Agustín Rossi (bloque de diputados del Frente para la Victoria), 17/04/2012

(40) Una medida que evidencia la contradicción, María Eugenia Estenssoro (senadora nacional por la Coalición Cívica), $17 / 04 / 2012$

(41) Una estatización que complica todo, Daniel Gustavo Montamat (fue presidente de YPF y secretario de Energía), $17 / 04 / 2012$

(42) El incierto rumbo económico, Juan J. Llach (sociólogo y economista, fue ministro de Educación de la Nación), $17 / 04 / 2012$

(43) Sobre la estatización de YPF, Alieto Guadagni (investigador del Instituto DiTella y ex secretario de Energía de la Nación), $17 / 04 / 2012$

(44) Estatizar sin Estado, Luis Alberto Romero (historiador y profesor de la Universidad de San Andrés y miembro del Club Político Argentino), 18/04/2012

(45) Mezquino acto de piratería económica, editorial publicado por Financial Times, 19/04/2012

(46) La presidenta argentina se niega a ingresar en el futuro, editorial publicado por The Washington Post, 21/04/2012

(47) YPF: la Nación y su energía, Hermes Binner (fue gobernador de Santa Fe y candidato a Presidente por el FAP), $22 / 04 / 2012$

(48) No falta petróleo, faltan instituciones, Roberto Cachanosky (economista), 22/04/2012

(49) Borrachera de patrioterismo nacionalista, Mario Vargas Llosa (escritor), 23/04/2012

(50) La UCR no puede acompañar otro error, Facundo Suárez Lastra (fue intendente de la ciudad de Buenos Aires), $23 / 04 / 2012$

(51) Carta a Cristina Kirchner por YPF, María Eugenia Estenssoro (senadora nacional por la Coalición Cívica), 25/04/2012

(52) Patriotismo con argumentos falaces, Federico Pinedo (diputado nacional de Pro), 26/04/2012

(53) La política de patear el tablero, Ricardo Esteves (licenciado en Ciencia Política) 26/04/2012

(54) Como un pez en petróleo, Martín Lousteau (economista, ex Ministro de Economía, diputado de la Nación Argentina con Frente Amplio UNEM), lanacion.com, 18/04/2012

(55) Aldo Ferrer: Enarsa quería tomar el papel de YPF pero no pudo, entrevista en El Tribuno de Salta, por Hugo Krasnobroda, lanacion.com, 20/04/2012 
B) Sample of Página 12's Discourse Analysis

Internal Opinion

(1) Finalmente, llegó el día, Alfredo Zaiat, 17/04/2012

(2) Banderas históricas y sintonía fina, Mario Wainfeld, 17/04/2012

(3) Día de la Independencia, Claudio Scaletta, 17/04/2012

(4) De la fantasía a los hechos, Martín Granovsky, 17/04/2012

(5) Esta no es la España que amamos, Mempo Giardinelli, 18/04/2012

(6) Un día histórico, Ricardo Foster, 19/04/2012

(7) Nuevo Estado, Luis Bruschtein, 21/04/2012

(8) A la cola, Alfredo Zaiat, 21/04/2012

(9) Repúblicas y republiquetas, Sandra Russo, 21/04/2012

(10) Marca España, Alfredo Zaiat, 22/04/2012

(11) YPF y la cuestión del relato, Edgardo Mocca, 22/04/2012

(12) Soberanía y poder, José Pablo Feinmann, 22/04/2012

(13) Y péguele fuerte, Eduardo Aliverti, 23/04/2012

(14) Sobrevivientes y sobrevividores, Juan Sasturain, 23/04/2012

(15) La vida después de Repsol, Washington Uranga, 24/04/2012

(16) Una soberana goleada, Mario Wainfeld, 26/04/2012

(17) Un debate que recién empieza, Raúl Dellatorre, 26/04/2012

External Opinion

(18) Lo que nos pertenece, Mario Rapoport (economista e historiador), 17/04/2012

(19) Seguridad energética, Víctor Bronstein (Director del Centro de Estudios de Energía, Política y Sociedad), 17/04/2012

(20) Dirección correcta, Ricardo Aronskind (docente UBA-Plan Fénix), 17/04/2012

(21) Activo estratégico, Ricardo de Dicco (Director del Centro Latinoamericano de Investigaciones Científicas y Técnicas), $17 / 04 / 2012$

(22) Petróleo y democracia, Horacio González (sociólogo, director de la Biblioteca Nacional), 18/04/2012 
(23) Política nacional de hidrocarburos, Andrés Asiain (economista lihes-Conicet), 18/04/2012.

(24) YPF pone la línea divisoria al rojo vivo, Hugo Yasky (secretario general de la CTA-Central de Trabajadores de la Argentina), 20/04/2012

(25) “Más de lo mismo: recetar, vigilar y castigar”, entrevista a Hernán Lorenzino (Ministro de Economía), por Raúl Dellatorre, $20 / 04 / 2012$

(26) El CIADI a la orden del día, Javier Echaide (abogado, investigador UBA), 20/04/2012

(27) Políticas que son amores, entrevista a Roberto Bacman (sociólogo del Centro de Estudios de Opinión Pública-CEOP), por Raúl Kollmann, 22/04/2012

(28) En la cuestión central hay acuerdo, entrevista a Daniel Filmus (senador del Frente para la Victoria, 28a), Luis Naidenoff (Unión Cívica Radical, 28b) y Rubén Giustiniani (socialista, 28c), por Sebastián Abrevaya, 22/04/2012

(29) "Fue lo peor que nos hizo el Estado neoliberal”, entrevista a Aldo Ferrer (embajador de Argentina en Francia), por Javier Lewkowicz, 22/04/2012

(30) “Investigaremos los daños ambientales”, entrevista con Francisco Pérez (gobernador de Mendoza), 23/04/2012

(31) Rajoy y otras penurias, Raúl Dorra (escritor, radicado en México), 23/04/2012

(32) Yacimientos, María Pía López (socióloga, docente de la UBA), 23/04/2012

(33) Argumentos contra las mentiras interesadas, Alejandro Grimson, Jorge Gaggero, Federico Schuster, Roberto Pianelli (et al., adheridos al texto del espacio de intelectuales Argumentos), 23/04/2012

(34) Los aspectos legales de la expropiación, entrevista con Arístedes Corti y Liliana Costante (abogados UBA), 24/04/2012

(35) La recuperación y el nacionalismo, Mario de Casas (presidente del ENRE-Ente Nacional Regulador de la Electricidad), $24 / 04 / 2012$

(36) Será una votación de mucho respaldo, entrevista con Miguel Ángel Pichetto (jefe del bloque de senadores del kirchnerismo), por Miguel Jorquera, 24/04/2012

(37) Unidad y organización, Martín Sabbatella (diputado nacional, presidente del bloque Frente Nuevo Encuentro), $24 / 04 / 2012$

(38) Un Estado recuperado, Daniel Filmus (senador nacional, Presidente de la Comisión de Relaciones Exteriores), $25 / 04 / 2012$

(39) Se equivocan de nuevo, Mark Weisbrot (Codirector del Center for Economic and Policy Research, en Washington), 25/04/2012 